\title{
SPG302 Reverses Synaptic and Cognitive Deficits Without Altering Amyloid or Tau Pathology in a Transgenic Model of Alzheimer's Disease
}

\author{
Laura Trujillo-Estrada ${ }^{1,4,5} \cdot$ Peter W. Vanderklish ${ }^{3} \cdot$ Marie Minh Thu Nguyen ${ }^{1} \cdot$ Run Rong Kuang ${ }^{1} \cdot$ Caroline Nguyen ${ }^{1}$. \\ Eric Huynh ${ }^{1}$. Celia da Cunha ${ }^{1}$. Dominic Ibarra Javonillo ${ }^{1}$ - Stefania Forner ${ }^{1}$ - Alessandra C. Martini ${ }^{1}$. Stella T. Sarraf ${ }^{3}$. \\ Vincent F. Simmon ${ }^{3} \cdot$ David Baglietto-Vargas $^{1,2,4,5} \cdot$ Frank M. LaFerla $^{1,2}$
}

Accepted: 11 October 2021 / Published online: 4 November 2021

(c) The Author(s) 2021

\begin{abstract}
Alzheimer's disease (AD) is conceptualized as a synaptic failure disorder in which loss of glutamatergic synapses is a major driver of cognitive decline. Thus, novel therapeutic strategies aimed at regenerating synapses may represent a promising approach to mitigate cognitive deficits in $\mathrm{AD}$ patients. At present, no disease-modifying drugs exist for $\mathrm{AD}$, and approved therapies are palliative at best, lacking in the ability to reverse the synaptic failure. Here, we tested the efficacy of a novel synaptogenic small molecule, SPG302 - a 3rd-generation benzothiazole derivative that increases the density of axospinous glutamatergic synapses - in 3xTg-AD mice. Daily dosing of 3xTg-AD mice with SPG302 at 3 and $30 \mathrm{mg} / \mathrm{kg}$ (i.p.) for 4 weeks restored hippocampal synaptic density and improved cognitive function in hippocampal-dependent tasks. Mushroom and stubby spine profiles were increased by SPG302, and associated with enhanced expression of key postsynaptic proteins — including postsynaptic density protein 95 (PSD95), drebrin, and amino-3-hydroxy-5-methyl-4-isoxazolepropionic acid receptor (AMPAR) - and increased colocalization of PSD95 with synaptophysin. Notably, SPG302 proved efficacious in this model without modifying $A \beta$ and tau pathology. Thus, our study provides preclinical support for the idea that compounds capable of restoring synaptic density offer a viable strategy to reverse cognitive decline in AD.
\end{abstract}

Keywords Alzheimer's disease $\cdot$ Dendritic spines $\cdot$ Synaptic deficits $\cdot 3 x T g-A D$ mice $\cdot$ SPG302 $\cdot$ Synaptic markers

\section{Introduction}

Alzheimer's disease (AD) is a progressive neurodegenerative disorder and the leading cause of dementia world-wide, estimated to afflict 50 million people by 2050 . In the USA,

Peter W. Vanderklish, Vincent F. Simmon, David Baglietto-Vargas, and Frank M. LaFerla contributed equally to this work

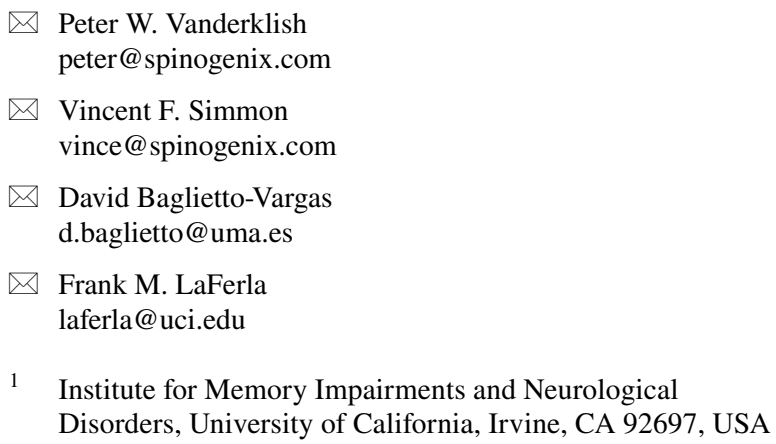

1 Institute for Memory Impairments and Neurological Disorders, University of California, Irvine, CA 92697, USA

the estimated total expenses for AD in 2020 is $\$ 305$ billion, with the cost expected to increase to more than $\$ 1$ trillion by 2050 [1]. Despite its prevalence, and greater than century long recognition as a clinical entity, disease-modifying therapies remain elusive [2]. In the last 20 years, over 150 clinical stage drugs have failed, dominated recently by a string of failures among therapies targeting amyloid beta $(\mathrm{A} \beta)$, and

2 Department of Neurobiology and Behavior, University of California, Irvine, CA 92697-1450, USA

3 Spinogenix Inc, 10210 Campus Point Drive, Suite 150, San Diego, CA 92121, USA

4 Departamento Biología Celular, Genetica y Fisiologia, Instituto de Investigacion Biomedica de Malaga-IBIMA, Facultad de Ciencias, Universidad de Malaga, Malaga, Spain

5 Centro de Investigacion Biomedica en Red sobre Enfermedades Neurodegenerativas (CIBERNED), Madrid, Spain 
the last FDA approval was in 2003 [3]. Current therapies for $\mathrm{AD}$, such as acetyl cholinesterase (AChE) inhibitors and $\mathrm{N}$-methyl-D-aspartate receptor (NMDAR) antagonists, afford only temporary symptomatic relief without modifying disease progression long term. Prompted by recent clinical failures and new insights into the etiology of $\mathrm{AD}$, a large pipeline of candidate therapeutics has emerged that addresses diverse aspects of $\mathrm{AD}$ pathogenesis at the molecular level [3]. While debate continues about which therapeutic focus points offer the best chance for disease modification, what is not in question is that for any therapeutic to be successful it must address one of the most functionally significant consequences of $\mathrm{AD}$ pathogenesis: synaptic failure [4].

$\mathrm{AD}$ is the prototypical synaptopathy, the best characterized member of an etiologically diverse set of neurodegenerative and other conditions in which the dysfunction and loss of synapses, primarily excitatory glutamatergic contacts, gives rise to deficits in cognition and other functions [4-8]. In AD, a progressive loss of glutamatergic synapses uncouples cortical and limbic circuits involved in learning, memory, and cognition [5, 6, 9-11]. Early histological studies that quantified numbers of synapses in biopsied $[5,12]$ or postmortem [5, 6, 13-18] brain tissue from AD patients revealed large reductions in synaptic density $(15-45 \%)$ in the hippocampus, entorhinal cortex, and in several neocortical and subcortical regions. Collectively, these data (reviewed in $[15,19,20])$ indicate that synapse loss occurs early in $\mathrm{AD}$ and progresses in a way that correlates strongly with cognitive decline. Importantly, morphometric and statistical considerations dictate that most of the synapses lost are glutamatergic contacts in which the postsynaptic elements are dendritic spines, the highly specialized, actin-rich protrusions of dendritic membrane that comprise the postsynaptic element in $\sim 90 \%$ of glutamatergic contacts [21]. The loss of axospinous contacts is particularly critical as they are loci of plasticities such as long-term potentiation (LTP) and depression (LTD) that alter the function of corticolimbic circuits in support of memory formation [22]. Correlations between the loss of dendritic spine synapses and cognitive decline are supported by work in mouse models [20, 23-28], by studies of the spine actin regulatory proteins spinophilin [29, 30], cofilin [31], and drebrin [32], as well as 3D electron microscopy in postmortem AD brain [33, 34]. The recent application of PET imaging of synaptic density to $\mathrm{AD}$, using the SV2A ligand UCB-J, has validated that synapse loss occurs in vivo and correlates with cognitive status, while also providing a clinically translatable biomarker of synapse loss $[35,36]$. Collectively, these and other observations raise the prospect that the regeneration of synapses, not merely the slowing of underlying molecular processes that lead to their dysfunction and loss, should be an explicit goal of $\mathrm{AD}$ drug development [5]. Observations that cognition is spared in patients who, despite robust $A \beta$ and neurofibrillary tangle pathology, have normal densities of dendritic spines (thought to be a basis of "cognitive reserve") support this notion [37].

Among a relatively short list of strategies to induce synaptogenesis in vivo [38], the modulation of cellular pathways that regulate the actin cytoskeleton is a particularly attractive approach in the context of AD where there is evidence of early dysregulation contributing to synaptic failure. Dendritic spine structure is determined in large part by highly branched assemblies of filamentous actin (F-actin) [39-41], dynamics in which contribute to spine shape changes during LTP and other plasticities [42-44]. Importantly, the assembly of branched F-actin networks is a necessary initial step in spine formation [45, 46]. The organization of F-actin in spines is regulated by an ecosystem of actin-binding proteins (ABPs) [41, 44, 47], the dysregulation of many of which has been shown to result in abnormalities in spine shape and cognitive function [44], including in AD. For example, expression levels of drebrin, a key postsynaptic ABP involved in the clustering and stabilization of F-actin in spines [47] and spine maturation, are reduced in the hippocampus and neocortex of AD patients, and in the superior temporal cortex of those with prodromal mild cognitive impairment, correlating with cognitive status [47-49]. In addition, activity of the F-actin severing protein, cofilin, is upregulated in AD. Dephosphorylation of cofilin activates its actin-severing function, which leads to disassembly of spine F-actin, spine retraction $[31,50]$, reduced LTP and spine density, and enhanced LTD [51-53]. Conversely, phosphorylation of cofilin inhibits this activity and is associated with spine enlargements underlying LTP consolidation [53]. Large reductions in phospho-cofilin are seen early in AD brain and in mouse models at a young age, contributing to synaptic failure and the appearance of characteristic cofilin/actin rods $[31,54,55]$. Such observations point to a compromised synaptic F-actin cytoskeletal network that contributes to synaptic failure and a reduced ability to form new synapses.

SPG302 is a 3rd-generation member of a novel class of pegylated benzothiazole derivatives that target an undisclosed regulator of the F-actin-based cytoskeleton and increase dendritic spine density in vitro and in vivo. Spines induced by SPG compounds comprise new synapses and exhibit the normal distribution of spine shapes found in wild type mouse brain, without inducing supraphysiological densities of synapses. Previous studies from our laboratory demonstrated that triple transgenic ( $3 \times \mathrm{Tg}-\mathrm{AD}) \mathrm{AD}$ mice develop cognitive and synaptic deficits at an early stage of the disease, well before the appearance of plaques and tangles [56]. These cognitive and synaptic alterations were associated with changes in AMPA receptor signaling, which is compromised early in the disease course in $\mathrm{AD}$ and ABPs, including drebrin [57]. In the present study, we 
tested the effects of SPG302 on cognition, synaptic density, key synaptic proteins, and the levels of $\mathrm{A} \beta$ and phosphorylated Tau in the 3xTg-AD mouse. In 6-month old 3xTg-AD mice, SPG302 was able to rescue deficits in cognition in hippocampal-dependent tasks and reverse substantial deficits in dendritic spines to densities that were not statistically different from wild type controls. This improvement in behavior was associated with increases in the expression of postsynaptic proteins (such as GluA1 and drebrin) and the co-localization of pre- and post-synaptic markers. Notably, these synaptic and cognitive enhancements were not associated with any changes in AD-like pathology as measured by hippocampal levels of $A \beta$ and phosphorylated Tau. These data advance SPG302 as a novel and promising therapeutic for $\mathrm{AD}$, and support the concept that promoting synapse regeneration through cytoskeletal acting small molecules may have broad utility in the synaptopathies.

\section{Materials and Methods}

\section{Transgenic Mice and Treatment Protocol}

Female homozygous 6-month-old 3xTg-AD and WT mice were used in the current study. The characterization of the $3 \times \mathrm{Tg}-\mathrm{AD}$ mice has been described previously [56]. In brief, two independent transgenes encoding human $\mathrm{APP}_{\text {swe }}$ and the human $\mathrm{Tau}_{\mathrm{P} 301 \mathrm{~L}}$ (both under the control of the mouse Thy1.2 regulatory element) were co-microinjected into single-cell embryos harvested from homozygous mutant $\mathrm{PS}_{\mathrm{M} 146 \mathrm{~V}}$ knockin (PS1-KI) mice [56].

Two different doses of the drug SPG302 were used: $3 \mathrm{mg} /$ $\mathrm{kg}$ and $30 \mathrm{mg} / \mathrm{kg}$. $3 \times \mathrm{Tg}-\mathrm{AD}$ and WT mice were randomly divided into three groups $(n=8-11)$ : WT vehicle $(n=11)$, WT SPG302 $3 \mathrm{mg} / \mathrm{kg}(n=11)$, WT SPG302 $30 \mathrm{mg} / \mathrm{kg}$ $(n=10), 3 \times$ vehicle $(n=10), 3 \times$ SPG302 $3 \mathrm{mg} / \mathrm{kg}(n=10)$, $3 \times \mathrm{SPG} 30230 \mathrm{mg} / \mathrm{kg}(n=10)$. SPG302 (diluted in $5 \%$ dimethyl sulfoxide DMSO) was administered by intraperitoneal injection once daily for 4 weeks. Animals treated with vehicle (5\% DMSO in phosphate buffered saline PBS) were used as a control group. SPG302 was supplied by Spinogenix, which provided funding for this study. All animal procedures were performed in accordance with $\mathrm{NIH}$, University of California guidelines and Use Committee at the University of California, Irvine.

\section{Behavioral Testing}

\section{Morris Water Maze}

Hidden Morris water maze (MWM) tests were conducted as described [58]. A circular aluminum tank (1.5-m diameter) was used for MWM experiments. Mice were trained to swim to a 14-cm-diameter circular Plexiglas platform submerged $1.5 \mathrm{~cm}$ beneath the surface of the water and invisible to the mice while swimming. The platform was located in a fixed position, equidistant from the center and the wall of the tank. Mice were subjected to four training trials per day. During each trial, mice were placed into the tank at one of four designated start points per day in a pseudorandom order. Mice were trained for as many days as needed to reach the training criteria of $25 \mathrm{~s}$ (escape latency). If the mice failed to find the platform within $60 \mathrm{~s}$, they were manually guided to the platform and allowed to remain there for $5 \mathrm{~s}$. The probe trial was assessed $24 \mathrm{~h}$ after the last training session and consisted of a 60-s free swim in the pool without the platform. Performance was monitored with the EthoVision XT video tracking system (Noldus Information Technology, Leesburg, VA).

\section{Contextual Fear Conditioning}

During training, mice were placed in the fear-conditioning chamber (Ugo Basile Fear Conditioning chambers and controller; 4 chambers each equipped with a Monochrome GigE camera) and allowed to explore for $2 \mathrm{~min} 30 \mathrm{~s}$ before receiving one electric foot shock (duration, $2 \mathrm{~s}$; intensity, $0.5 \mathrm{~mA}$ ). Animals were returned to the home cage $30 \mathrm{~s}$ after the foot shock. Twenty-four hours later, behavior in the conditioning chamber was video recorded during $5 \mathrm{~min}$ and subsequently analyzed for freezing, which was defined as the absence of all movement except for respiration. Mice freezing activity was analyzed with Noldus Ethovision XT with the fear conditioning module.

\section{Tissue Preparation}

After euthanasia, the animals were perfused transcardially with $0.1 \mathrm{M}$ phosphate-buffered saline (PBS, pH7.4). Next, the hippocampus was used to collect synaptosomes [59], to stain with Golgi solution [60], for MSD analysis and for immunohistological stain.

\section{Golgi Stain}

Mice were perfused transcardially with $0.1 \mathrm{M}$ phosphatebuffered saline (PBS, pH 7.4), and brains were processed using superGolgi Kit (Bioenno Tech LLC, Santa Ana, CA), as described [60]. Brains were incubated for 11 days in impregnation solutions, followed by 2 -day incubation in a post-impregnation solution. Once the impregnation of neurons was complete, thick $(150 \mu \mathrm{m})$ free-floating sections were obtained using a HA752 vibratome (Campden Instruments Ltd, Lafayette, IN) and serially collected in a mounting buffer. Sections mounted on coated slides were stained and post-stained respectively for $20 \mathrm{~min}$, dehydrated in 
graded ethanol, cleared with xylene, and coverslipped with DPX (VWR, Visalia, CA, USA) mounting medium.

\section{Dendritic Spine Analysis}

Stereological quantifications were performed using Neurolucida software from Microbrightfield Bioscience (MBF Bioscience, Williston, VT, USA) to determine the number of spines in the stratum radiatum (sr) of the hippocampal CA1 region. Briefly, every second section was used through the entire antero-posterior extent of the hippocampus (between $-1.46 \mathrm{~mm}$ anterior and $-3.40 \mathrm{~mm}$ posterior to Bregma according to the atlas of Franklin and Paxinos, Third Edition, 2007). In the CA1 region, sr region was defined using a $5 \times$ objective and spines were counted using a $100 \times / 1.4$ objective ( $5-6$ sections per animal, $n=5$ animals per group).

\section{Synaptosome Extracts}

Synaptosome extracts were prepared as described previously [59]. Briefly, the hippocampus was homogenized (using a Dounce homogenizer) in DEPC-treated water (Ambion) supplemented with $0.32 \mathrm{M}$ sucrose, $20 \mathrm{mM}$ Tris- $\mathrm{HCl}$, 0.5 M EDTA, and 0.5 M EGTA (pH 7.4), containing complete protease (Sigma) and phosphatase inhibitor cocktails (Sigma). After homogenization, the crude synaptosomal fraction (synaptosomes plus mitochondria) was isolated by two sequential centrifugations $(1,500 \times g, 10 \mathrm{~min}$ followed by $12,500 \times g, 20 \mathrm{~min}$; at $4{ }^{\circ} \mathrm{C}$ ). The protein content of the synaptosomal fractions was determined using the Bradford assay. For western blot experiments, synaptosomal preparations were temporally stored at $-80^{\circ} \mathrm{C}$.

\section{Immunoblotting}

Equal amounts of protein $(20 \mu \mathrm{g})$ were separated on $10 \%$ Bis-Tris gel (Invitrogen, Carlsbad, CA) and transferred to nitrocellulose membranes. Membranes were blocked for $1 \mathrm{~h}$ in 5\% (w/v) suspension of Bovine Serum Albumin (BSA; Gemini Bio-Products, West Sacramento, CA, USA) in 0.2\% Tween 20 Tris-buffered saline (pH 7.5). After blocking, the membranes were incubated overnight at $4{ }^{\circ} \mathrm{C}$ with one of the following primary antibodies: anti-Drebrin (1:1000; Enzo Life Sciences), anti-GluA1 (1:1000; Cell Signaling), anti- $p$ GluA1 (Ser845; 1:1000; Cell Signaling), anti-postsynaptic density protein 95 (PSD95; 1:1000; Cell Signaling), antisynaptic vesicle glycoprotein 2 (SV2A; 1:1000; Abcam), anti-fascin (1:1000; Abcam), anti-p-fascin (1:1000; Abcam), anti-synaptophysin (1:2000; Abcam), anti- $\beta$-tubulin (1:5000; Cell Signaling). The membranes were washed in tween-TBS for $20 \mathrm{~min}$ and incubated at $20^{\circ} \mathrm{C}$ with the specific secondary antibody at a dilution of 1:10,000 (Pierce Biotechnology) for $60 \mathrm{~min}$. The blots were developed using Super Signal (ThermoFisher Scientific, Rockford, IL, USA).

\section{Immunohistochemistry}

Coronal free-floating Sects. ( $40 \mu \mathrm{m}$ thick) were pretreated with 3\% H2O2/3\% methanol in Tris-buffered saline (TBS) for 30 min to block endogenous peroxidase activity. After TBS wash, sections were incubated first in TBS with $0.1 \%$ Trition X-100 (TBST) for $15 \mathrm{~min}$, and then in TBST with $2 \%$ bovine serum albumin (BSA, Sigma-Aldrich) for $30 \mathrm{~min}$. Sections were incubated with 6E10 (1:1000; BioLegend, San Diego, CA, USA), anti-HT7 (1:500; Thermo Scientific), and anti-AT180 (1:500; Thermo Scientific), in TBS + 5\% normal horse serum overnight at room temperature. Sections were then incubated with biotinylated anti-mouse, 1:500 in $\mathrm{TBS}+2 \% \mathrm{BSA}+5 \%$ normal serum for $1 \mathrm{~h}$ at $20^{\circ} \mathrm{C}$, followed by Vector $\mathrm{ABC}$ Kit and $\mathrm{DAB}$ reagents (Vector Laboratories, Burlingame, CA, USA) to visualize staining.

For double fluorescent stain, sections were incubated with anti-PSD95 (1:250; Invitrogen) and anti-synaptophysin (1:700; Sigma) overnight at $4{ }^{\circ} \mathrm{C}$. Next, sections were incubated in secondary goat anti-mouse alexa-fluor 555 for synaptophysin and goat anti-rabbit alexa-fluor 488 for PSD95 antibody (Invitrogen) for $1 \mathrm{~h}$. Sections were then mounted and coverslipped with Fluoromount-G (Southern Biothech).

\section{Quantitative Analyses}

The biochemical data were quantitatively analyzed using Image J 1.36b software. For synaptophysin/PSD95 quantification, fluorescent sections were imaged with a Leica DM 2500 laser scanning confocal with identical laser and detection settings. Using a $63 \times$ oil objective $($ zoom $=4), Z$ stacks $(0.34 \mu \mathrm{m}$ interval, within a depth of $3 \mu \mathrm{m})$ for each Sect. (6 sections per animal, $n=5$ ) were collected per area of interest (CA1, stratum radiatum). Number of synaptic puncta and colocalization between PSD95 and synaptophysin puncta (number of colocalized spots at a distance of $200 \mathrm{~nm}$ or less) were quantified using Bitplane Imaris software (spots function).

\section{$A \beta$ and Tau ELISA}

Levels of $A \beta$ and Tau were measured using the V-Plex $A \beta$ peptide panel 1 kit and phospho-Thr231/total tau kit, respectively. For A $\beta$ ELISA, $150 \mu 1 /$ well of Diluent 35 was added in a plate and incubated for $1 \mathrm{~h}$ at room temperature. After the washes, $25 \mu \mathrm{l}$ of detection antibody solution and $25 \mu \mathrm{l}$ of samples (soluble fraction, S1), calibrators or controls, were added to each well and incubated for $24 \mathrm{~h}$ at $4{ }^{\circ} \mathrm{C}$. Then, samples were washed, $150 \mu \mathrm{l}$ of Read buffer was added to each well, and the plate was read in the MESO QuickPlex 
SQ 120 instrument. For tau ELISA, $150 \mu \mathrm{l} /$ well of Blocker A solution was first added and incubated for $1 \mathrm{~h}$ at room temperature. Then, the plate was washed and $25 \mu \mathrm{l}$ of calibrator or samples was added in each well. Next, the plate was washed and incubated in the detection antibody solution $(25 \mu \mathrm{l})$ for $1 \mathrm{~h}$ at room temperature. Finally, samples were washed, added $150 \mu \mathrm{l}$ of Read buffer, and read in the MESO QuickPlex SQ 120 instrument. The data obtained were normalized with the protein concentration of each sample.

\section{In Vitro Assay}

Primary neurons cultured from hippocampi of newborn rats were utilized to evaluate the effect of SPG302 on dendritic spine density in vitro. Briefly, neurons from the hippocampus of 3 newborn rats were cultured and plated in a 24-well plate and were cultured for 14 days. At day 1, the culture medium was replaced with plain medium. At day $4,5 \mathrm{nM}$ of araC was added in order to stop glial cell mitosis and to avoid background staining, multi-dimensional plains of focus, and excessive nutrient consumption. At day 14, SPG302 was added to the culture wells in several concentrations $(0.1,0.3,1,3$, and $10 \mu \mathrm{M})$ using DMSO as a solvent. At day 15, cells were fixed on coverslips using methanol and double-stained with antibody against PSD95 for synaptic count of spines on the basal dendrites and antibody against synaptobrevin II for presynaptic imaging. DAPI staining was used for cell nuclei count. The number of spines per $20 \mu \mathrm{m}$ length of dendrite was compared to the untreated control group. Vehicle group was treated with $0.1 \%$ DMSO.

For immunocytochemistry, coverslips with primary rat hippocampal neurons at day 15 were fixed with $100 \%$ frozen methanol and permeabilized with $0.02 \%$ Triton X-100. Neurons were then incubated in BSA for $1 \mathrm{~h}$ at room temperature followed by incubation with respective antibodies: mouse-anti-PSD95 (Thermofisher) and rabbit-anti-Synaptobrevin II (SYSY), and later on secondary antibodies Alexa Fluor 488-conjugated anti mouse antibody and Alexa Fluor 594-conjugated anti rabbit antibody. Coverslips were mounted on slides using fluorescent mounting medium with DAPI (Gbi). Approximately 10 images from different areas of a total of 3 coverslips per treatment group were taken. Imaging was done using BX43 Olympus microscope driven by the standard "CellSens" software by Olympus. Images were taken under $60 \times$ water-dipping objective using DP74 camera (Olympus). Dendritic spines were detected automatically using ImageJ software. To perform analysis on the PSD95 content puncta, an exclusion threshold was set at 5 points above the background. Irrelevant content, such as cell bodies, glia and synapses out of the focus plain were dimmed. To estimate the neurites length, an ImageJ plugin - "NeuronJ" was used.

\section{Statistical Analyses}

All data were analyzed by one-way or two-way analysis of variance (ANOVA), followed by Tukey's comparisons using Graphpad Prism 8® software (Graphpad Prism Inc., San Diego, CA, USA). The significance was set at $95 \%$ of confidence. All values are presented as mean \pm SEM.

\section{Results}

\section{SPG302 Treatment Mitigates the Behavioral Impairments in 3xTg-AD Mice}

To evaluate the cognitive effects of SPG302, wild type (WT) and 3xTg-AD mice at 6 months of age were dosed daily for 4 weeks with either vehicle or SPG302 at 3 or $30 \mathrm{mg} / \mathrm{kg}$ (i.p.), with behavioral assessments conducted during the 4th week, followed by sacrifice for performance of histological and biochemical assays in brains from the same animals. To assess whether SPG302 rescues cognitive function in 3xTg-AD mice, we evaluated spatial memory in vehicle and SPG302-treated WT and 3xTg-AD mice using the Morris water maze (MWM) test (Fig. 1A). 3xTg-AD mice treated with vehicle showed severe impairments in learning during acquisition of the spatial task compared to vehicle-treated WT mice. These deficits were reversed by SPG302 treatment at both 3- and $30-\mathrm{mg} / \mathrm{kg}$ doses (Fig. 1A1). In addition, mice were tested $24 \mathrm{~h}$ after the last training trial to evaluate memory retention. Vehicle-treated 3xTg-AD mice displayed significant impairments in retention as measured by the frequency of visits to, and time spent in, the target area (Fig. 1A2-A3). Treatment of 3xTgAD mice with SPG302 at 3 and $30 \mathrm{mg} / \mathrm{kg}$ significantly improved memory retention in these assays. Moreover, the cognitive impairments observed in 3xTg-AD vehicle mice were not attributed to motor deficits, since no significant changes were noted for distance traveled and velocity (Fig. 1A4-A5) in any of the treatment groups (including WT and $3 \times$ Tg-AD mice).

To further characterize the memory enhancing effects of SPG302 in 3xTg-AD mice, we used contextual fear conditioning (CFC) paradigm, another hippocampaldependent task (Fig. 1B). Vehicle-treated 3xTg-AD mice showed a markedly reduced freezing response to the conditioning context compared to WT vehicle mice. The duration of the freezing response was significantly increased after SPG302 treatment in 3xTg-AD mice and was similar to WT levels. Overall, these data suggest that SPG302 reverses hippocampal learning and memory deficits in 3xTg-AD mice. 

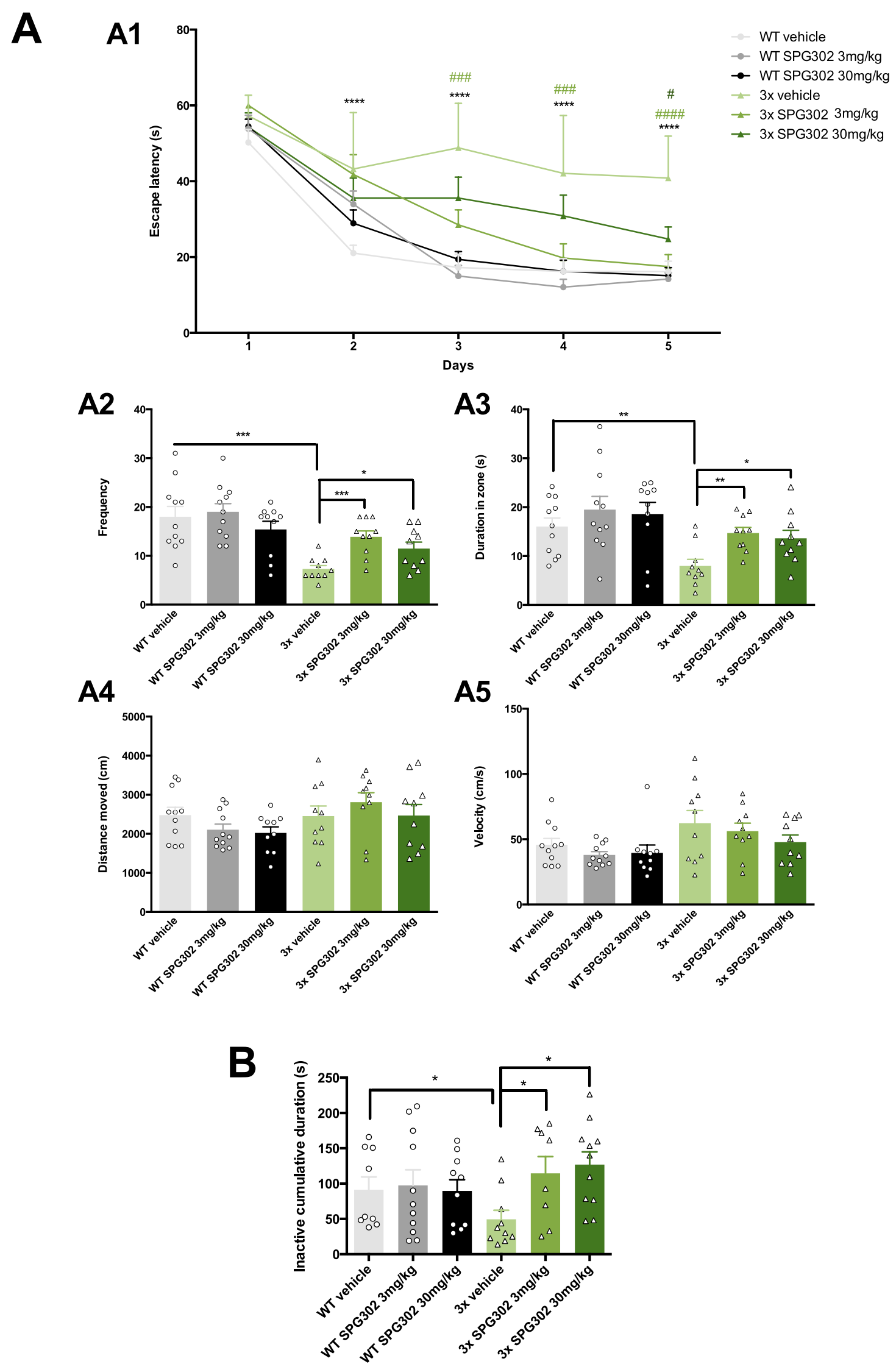
4Fig. 1 SPG302 restores behavioral deficits in 3xTg-AD mice. (A) Mice were trained on the spatial reference version of the MWM at 7 months of age. Acquisition curves (A1) are shown for the 5 days of training on the MWM. Two-way ANOVA: trials $[\mathrm{F}(4,285)=92.63$, $p<0.0001]$, treatment $[\mathrm{F}(5,285)=30.33, p<0.0001]$, and interaction $[\mathrm{F}(20,285)=2.699, p=0.0002]$, Tukey's multiple comparison test, $* * * * p<0.0001, * * * p<0.001, * p<0.05$ (significance indicated for $3 \times$ vehicle: * versus WT vehicle, \# versus $3 \times$ SPG302 $3 \mathrm{mg} / \mathrm{kg}$ or $30 \mathrm{mg} / \mathrm{kg}$ ). (A2) Frequency of WT vehicle, WT SPG302 $3 \mathrm{mg} /$ $\mathrm{kg}$, WT SPG302 $30 \mathrm{mg} / \mathrm{kg}, 3 \times$ vehicle, $3 \times$ SPG302 $3 \mathrm{mg} / \mathrm{kg}$ and $3 \times$ SPG302 $30 \mathrm{mg} / \mathrm{kg}$ were measured $24 \mathrm{~h}$ after the last training session. Frequency is reduced in $3 \times$ vehicle compared to WT vehicle. However, SPG302 treatment rescue frequency values in $3 \times \mathrm{Tg}-\mathrm{AD}$ mice to WT mice. One-way ANOVA, $* * * * p<0.0001$, $\mathrm{F}(5,56)=7.828$, Tukey's multiple comparisons test, $* * * p<0.001$, $* p<0.05$. (A3) Duration in zone. Time spent in the platform quadrant is reduced in 3x-vehicle vs WT-vehicle group. SPG302 treatment in $3 \times T g-A D$ mice increase the duration in zone time, similar to WT mice group. One-way ANOVA, $* * p=0.0017, \mathrm{~F}(5,56)=4.458$, Tukey's multiple comparisons test, ${ }^{* *} p<0.01, * p<0.05$. Distance moved (A4) and velocity (A5) showed no differences between groups. (B) $\mathrm{CFC}$ analysis. $3 \times$ vehicle showed a reduction in the inactivity duration which was recovered with SPG302 treatment to WT levels. $t$-test, ${ }^{*} p<0.05 . n=8-11$ per group. The values represent means \pm SEM

\section{SPG302 Restores the Numbers of Postsynaptic Puncta and Their Colocalization with Presynaptic Elements in 3xTg-AD Mice}

We next evaluated whether the SPG302-induced improvement of 3xTg-AD mice in hippocampal-dependent memory tasks was associated with changes in pre- and postsynaptic protein puncta in the stratum radiatum of hippocampal field CA1 using immunofluorescence microscopy. Analysis of sections immunolabeled for the postsynaptic scaffolding protein, PSD95, revealed a significant deficit in the number of postsynaptic puncta (Fig. 2A1a-1d, and B1) in $3 \times \mathrm{Tg}-\mathrm{AD}$ mice treated with vehicle (Fig. 2A1b) compared to WT vehicle mice (Fig. 2A1a), which was restored by SPG302 treatment at both 3 and $30 \mathrm{mg} / \mathrm{kg}$ doses (Fig. 2A1c, 1d). Decreases in the number of presynaptic elements containing synaptophysin in $3 \times \mathrm{Tg}-\mathrm{AD}$ mice were also observed, but this was not rescued by SPG302 treatment at 3 or $30 \mathrm{mg} / \mathrm{kg}$ (Fig. 2A2a-2d and B2). However, SPG302 treatment (at $30 \mathrm{mg} / \mathrm{kg}$ ) rescued deficits in the colocalization of PSD95- and synaptophysin-labeled elements (Fig. 2A3a-3d) in 3xTg-AD mice at $30 \mathrm{mg} / \mathrm{kg}$ mice (Fig. 2B3), considered an immunohistochemical measure of possible functional synapses.

\section{SPG302 Reverses Large Decreases in Dendritic Spine Density in 3xTg-AD Mice and Enhances Spinogenesis In Vitro}

SGP302 and its prototype compounds promote the formation of new dendritic spine synapses through a mechanism of action that targets the F-actin-based cytoskeleton. We thus sought to validate that SPG302 increases dendritic spine density in the $3 \mathrm{xTg}-\mathrm{AD}$ model as expected and as suggested by both the behavioral immunohistochemical data. We performed Golgi staining and stereological quantification of dendritic spines in the stratum radiatum (sr) of hippocampal field CA1 (Fig. 3A1, A2). The stereological quantification indicated that $3 \times \mathrm{Tg}-\mathrm{AD}$ mice treated with vehicle have significantly reduced dendritic spine density (Fig. 3A1, A2) compared to vehicle-treated WT mice, particularly in mushroom and stubby-type spine profiles. These large deficits in dendritic spines in 3xTg-AD mice $(\sim 35-50 \%)$ were reversed by treatment with SPG302 at 3 and $30 \mathrm{mg} / \mathrm{kg}$ (Fig. 3A1, A2), which increased spine density in 3xTg-AD mice to levels not statistically different from those seen in vehicle-treated WT mice.

We also evaluated the effect of SPG302 in vitro on the density of dendritic spines on primary hippocampal neurons from rat (Supplementary Fig. 1A). Treatment with SPG302 at concentrations of $0.1,0.3,1,3$, and $10 \mu \mathrm{M}$ resulted in a statistically significantly increase in the mean spine density (spines $/ 20 \mu \mathrm{m}$ ) compared to the vehicle group $(37.41 \pm 5.88$, $33.72 \pm 2.75,35.65 \pm 3.68,45.97 \pm 3.89,24.71 \pm 2.33$, respectively, vs. $12.54 \pm 1.81$ in vehicle controls). Treatment with vehicle $(0.1 \%$ DMSO) did not increase the mean spine density compared to an untreated control group $(14.76 \pm 1.02$ vs. $12.54 \pm 1.81$, respectively).

To further understand the nature of SPG302's synaptic rescue effects, we measured the levels of several key synaptic proteins including Drebrin, GluA1, p-GluA1, PSD95, synaptic vesicle glycoprotein A (SV2A), synaptophysin and the molecular target of SPG302, and synaptophysin, by western blot (WB) in hippocampal synaptosomes (Fig. 3B1) prepared from a subset of animals tested in behavioral assays. Changes in the levels and activity of these synaptic markers have been associated with memory impairments in $\mathrm{AD}[38$, $57,61,62]$. In accord with the observed spine deficits $3 \times \mathrm{Tg}$ $\mathrm{AD}$ mice, WB analysis revealed significant decreases in the steady-state levels of Drebrin, PSD95, and the p-GluA1/ GluA1 ratio in 3xTg-AD vehicle mice compared to WT vehicle mice. The levels of these proteins were significantly improved with SPG302 treatment (Fig. 3B1, B2). These data suggest that the structural effects of SPG302 on dendritic spine density are accompanied by increases in key scaffolding, actin regulatory, and glutamatergic-signaling proteins involved in the formation and plasticity of glutamatergic synapses.

\section{SPG302 Does Not Alter A $\beta$ or Tau Pathology in 3xTg-AD Mice}

Accumulation of $\mathrm{A} \beta$ and hyperphosphorylated Tau are the hallmark features of AD molecular pathology [63], so any drug affecting $\mathrm{AD}$ progression - even if not targeting 

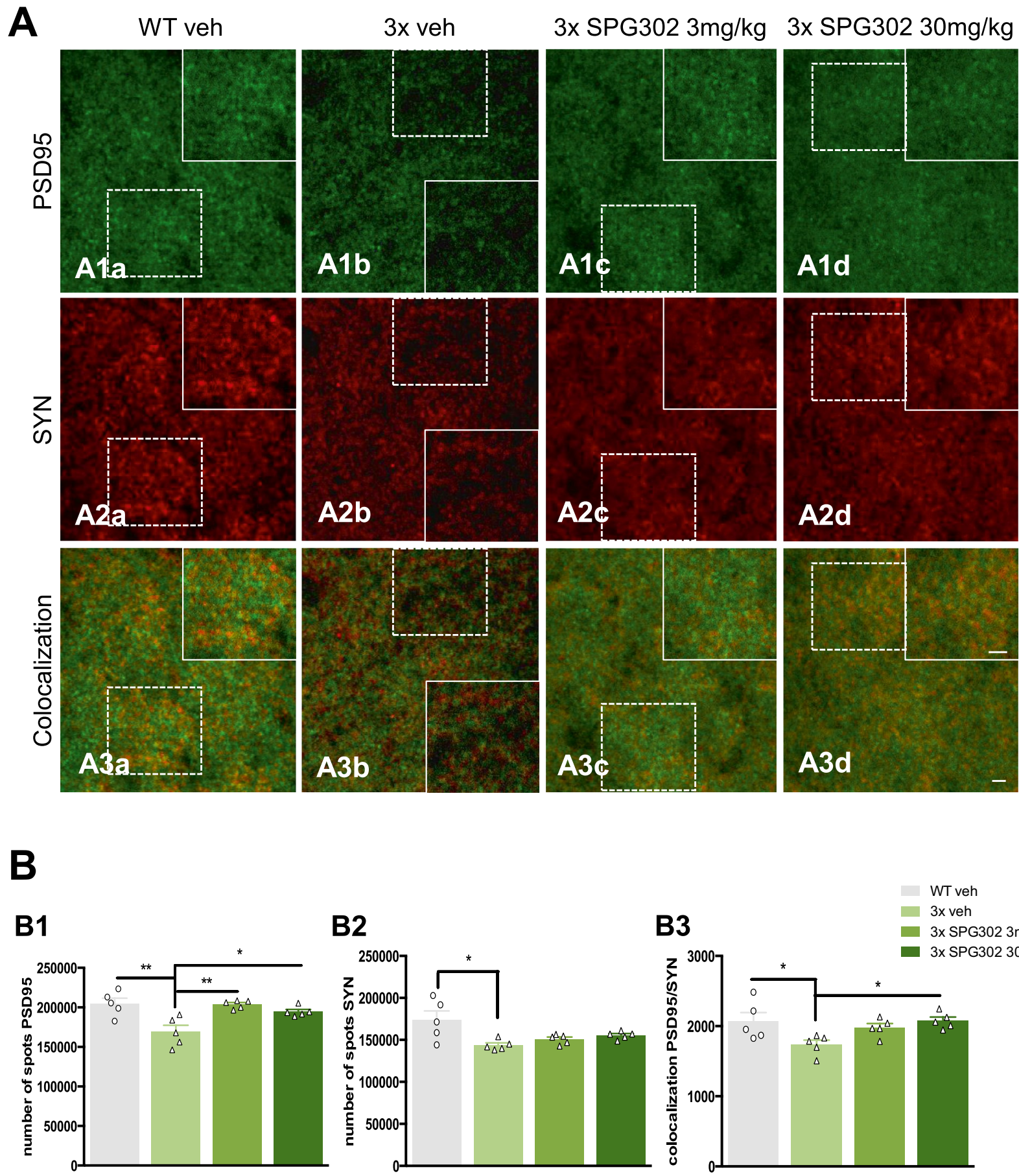

B2

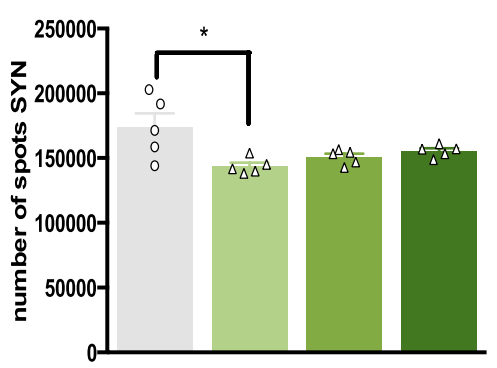

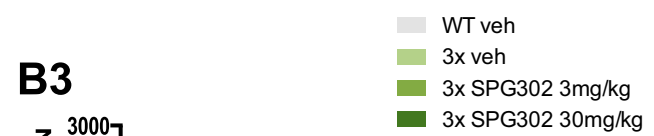

Fig. 2 SPG302 treatment rescue synaptic puncta density in 3xTg-AD mice. (A) Confocal images of PSD95 and synaptophysin in the stratum radiatum of CA1 hippocampal area. (B) Quantitative analysis of these images revealed a reduction in the number of PSD95 (B1) (one-way ANOVA, $* * p=0.0013, \mathrm{~F}(3,16)=8.537$, Tukey's multiple comparisons tests, $* * p<0.01, * p<0.05$ ) and SYN (B2) (one-way ANOVA, $* p=0.0134, \mathrm{~F}(3,16)=4.894$, Tukey's multiple comparisons

these pathways directly - may alter one or both of these characteristics. However, A $\beta$ pathology was not altered tests, $* p<0.05)$ puncta as well as the colocalization between both markers $(\mathbf{B 3})$ (one-way ANOVA, $* p=0.0274, \mathrm{~F}(3,16)=3.960$, Tukey's multiple comparisons tests, $* p<0.05)$ in $3 \times$ vehicle compared to WT vehicle. SPG302 treatment restores PSD95 number of spots and colocalization. However, no changes were observed with the treatment for the presynaptic marker synaptophysin. $n=5$ per group. The values represent means \pm SEM. Scale bars: $50 \mu \mathrm{m}$

by SPG302 treatment in 3xTg-AD mice as measured by immunohistochemistry (Fig. 4A1a-A1c) and by ELISA 
A

A1
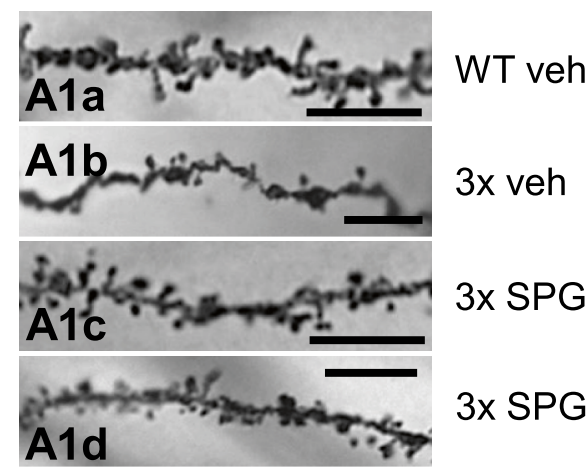

$3 x$ veh

3x SPG302 3mg/Kg

3x SPG302 30mg/Kg

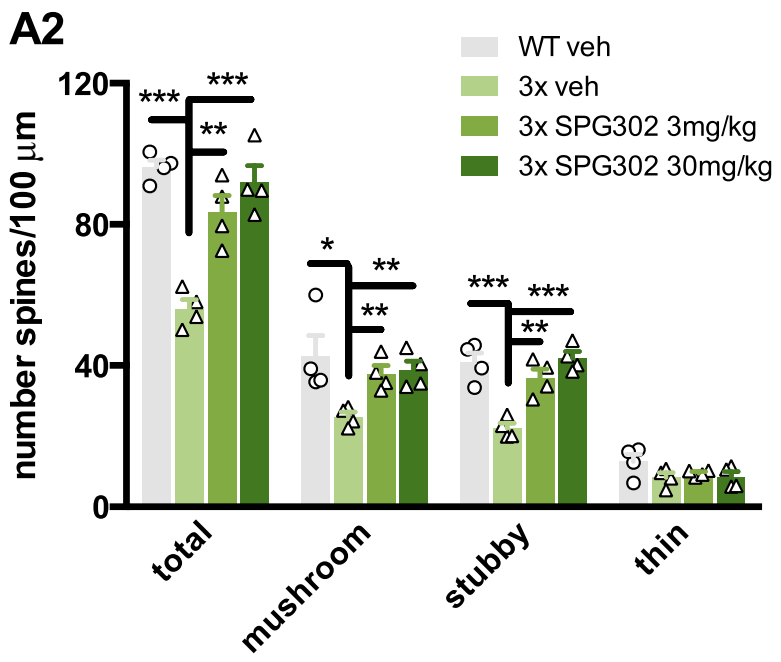

B2

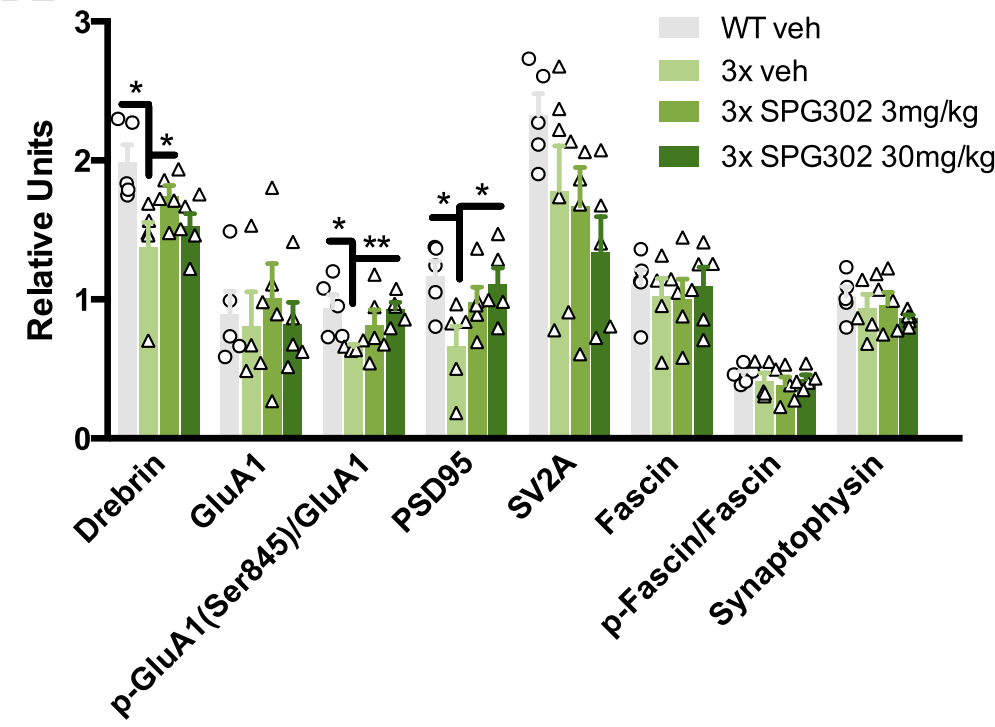

Fig. 3 SPG302 improve dendritic spine density in 3xTg-AD mice and synaptic-related proteins. (A) Dendritic spines analysis in WT vehicle, $3 \times$ vehicle, $3 \times$ SPG302 $3 \mathrm{mg} / \mathrm{kg}$ and $3 \times$ SPG302 $30 \mathrm{mg} /$ $\mathrm{kg}$. Light microscopic images of radiatum layer in CA1 subfield (A1) in WT vehicle (A1a), $3 \times$ vehicle (A1b), $3 \times$ SPG302 $3 \mathrm{mg} / \mathrm{kg}$ (A1c) and $3 \times$ SPG302 $30 \mathrm{mg} / \mathrm{kg}$ (A1d). (A2) Stereological quantification showed a significant decrease in the density of total dendritic spines in $3 \mathrm{x}$-vehicle group compared to WT-vehicle group (oneway ANOVA, $* * * * p<0.0001, \mathrm{~F}(3,12)=23.28$, Tukey's multiple comparisons tests, $* * * p<0.001$, **p $p<0.01$ ), in mushroom (oneway ANOVA, ${ }^{*} p=0.0249, \mathrm{~F}(3,12)=4.482$, Tukey's multiple comparisons tests, $* * p<0.01, * p<0.05$ ) and stubby spines (one-way ANOVA, $* * * p<0.0001, \mathrm{~F}(3,12)=16.80$, Tukey's multiple comparisons tests, $* * * p<0.001, * * p<0.01)$. Notably, SPG302 treatment in $3 \mathrm{xTg}-\mathrm{AD}$ mice rescue total, mushroom and stubby spines compared to vehicle ( $n=4$ per group). (B) Immunoblot analysis of Drebrin, GluA1, p-GluaA1, PSD95, SV2A, Fascin, p-Fascin and synaptophysin in hippocampal synaptosome from WT vehicle, $3 \times$ vehicle, $3 \times$ SPG302 $3 \mathrm{mg} / \mathrm{kg}$ and $3 \times \mathrm{SPG} 30230 \mathrm{mg} / \mathrm{kg}$ group are shown in alternate lanes (B1). (B2) Quantification normalized to $\beta$-tubulin for Drebrin, GluA1, PSD95, SV2A, Fascin and synaptophysin, normalized to GluA1 for p-GluA1, and to Fascin for p-Fascin, and expressed as relative units, showed a significant reduction in Drebrin, p-GluA1 and PSD95 in $3 \times$ vehicle vs WT vehicle group. Notably, a significant increase in Drebrin $(3 \times \mathrm{SPG} 3023 \mathrm{mg} / \mathrm{kg})$, p-GluA1 $(3 \times$ SPG302 $30 \mathrm{mg} / \mathrm{kg})$ and PSD5 $(3 \times$ SPG302 $30 \mathrm{mg} / \mathrm{kg})$ is shown in $3 \times$ treated with SPG302 compared to $3 \mathrm{x}$-vehicle group. Unpaired $t$ test, ${ }^{*} p<0.01, * p<0.05 . n=5$ per group. The values represent means \pm SEM. Scale bars: $6.25 \mu \mathrm{m}$ 
A

$3 x$ veh

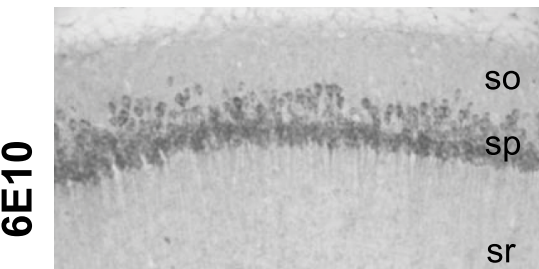

A1a
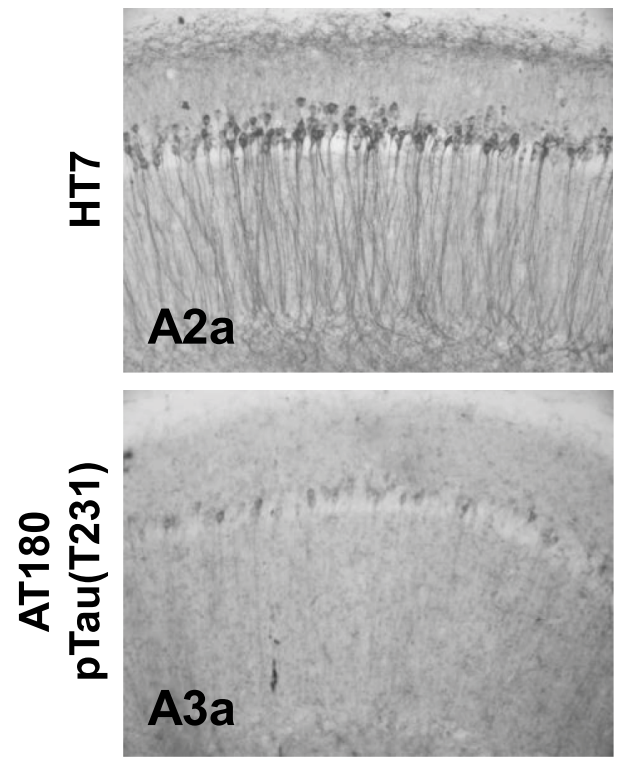

B

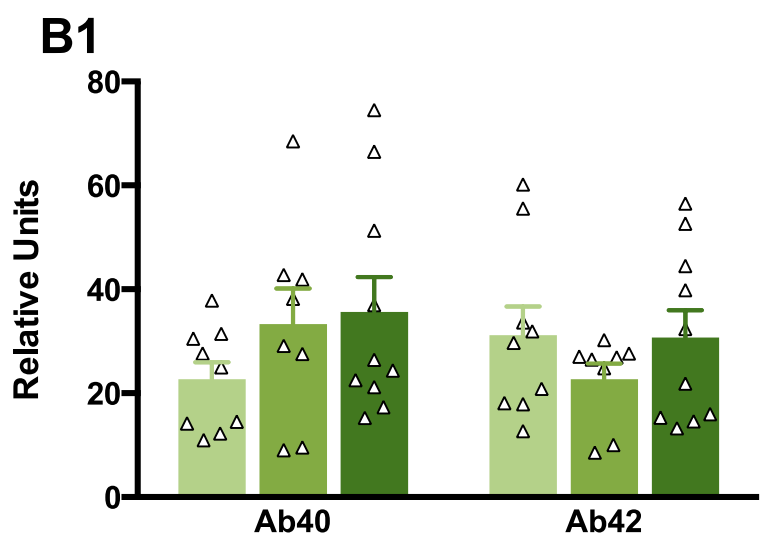

Fig. 4 SPG302 treatment does not alter A $\beta$ or tau pathology. (A) Light microscopic images stained with 6E10 (A1a-A1c), HT7 (A2aA2c) and AT180 (A3a-A3c) in $3 \times$ vehicle (A1a, A2a and A3a), $3 \times$ SPG302 $3 \mathrm{mg} / \mathrm{kg}$ (A1b, A2b and A3b) and SPG302 $30 \mathrm{mg} /$ $\mathrm{kg}$ (A1c, A2c and A3c). No differences were detected in the staining of these three markers between the different groups. (B) Amyloid

\section{3x SPG302 30mg/Kg}

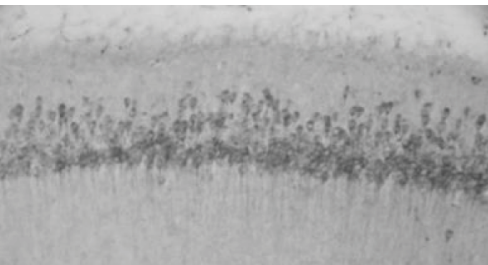

A1c
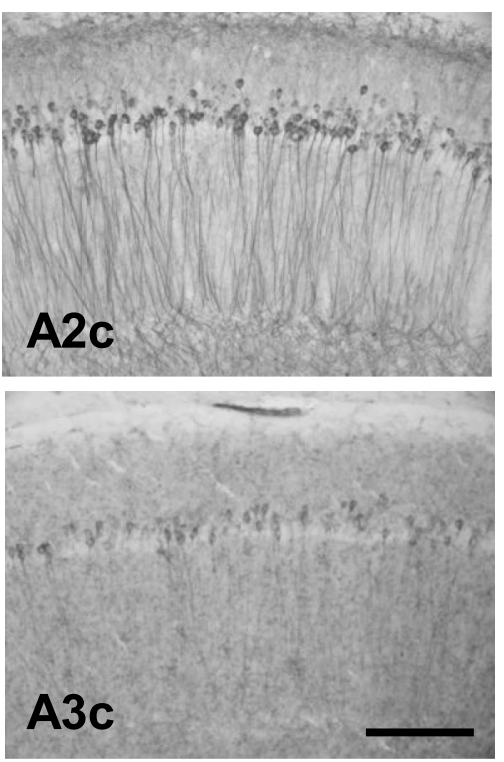

\section{$\mathrm{A} 3 \mathrm{C}$}
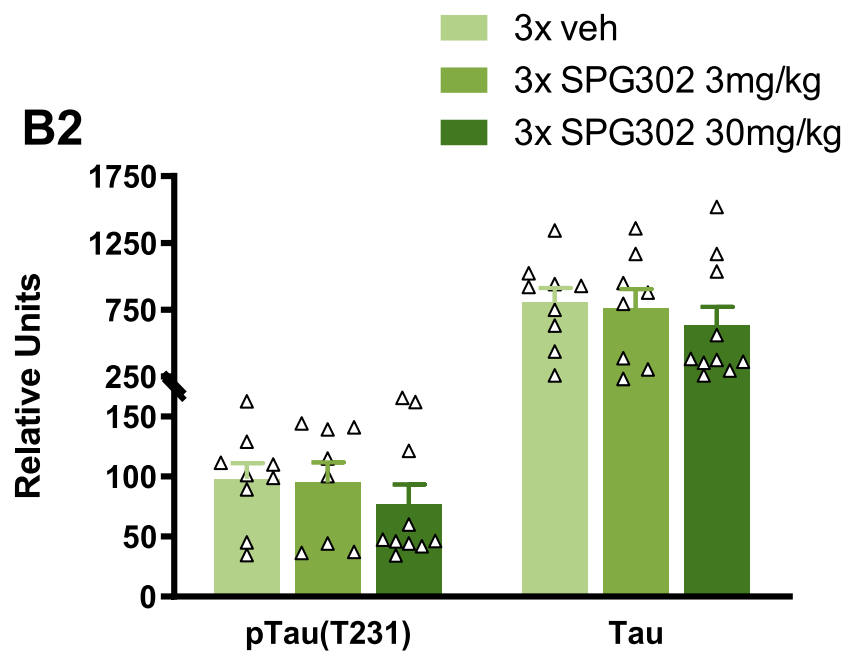

(B1), pTau (B2) and Tau (B2) levels measured by ELISA in $3 \times$ vehicle, $3 \times$ SPG302 $3 \mathrm{mg} / \mathrm{kg}$ and $3 \times \mathrm{SPG} 30230 \mathrm{mg} / \mathrm{kg}$ revealed no differences for any of these markers between the groups. $n=8-10$ per group. The values represent means \pm SEM. so, stratum oriens; $s p$, stratum pyramidale; sr, stratum radiatum; slm, stratum lacunosummoleculare. Scale bars: $100 \mu \mathrm{m}$ 
(Fig. 4B1). Moreover, immunohistochemical and ELISA analysis revealed that neither steady-state Tau (HT7) nor phospho-Tau species recognized by AT180 (Thr231) were altered by SPG302 treatment (Fig. 4A2a-A3c and B2). The data suggest that the effect of SPG302 in restoring synaptic and cognitive deficits in 3xTg-AD was not associated with any change in $A \beta$ and/or Tau pathology.

\section{Discussion}

Synapse loss is an early and nodal event in the pathogenesis of $\mathrm{AD}$ that correlates with cognitive decline better than the hallmark features of AD brain, amyloid plaques, and neurofibrillary tangles $[16,19,20]$. However, while the rationale for considering synaptic regeneration as an endpoint in $\mathrm{AD}$ is very strong, the candidate therapeutics and data that can be directed toward validating this hypothesis are sparse at best [38]. In this study, we demonstrated that a novel spinogenic small molecule, SPG302, is capable of reversing deficits in cognition and synaptic density in a mouse model of AD, effects that were accompanied by increases in the expression of key postsynaptic proteins and the colocalization of pre- and post-synaptic markers. The efficacy of SPG302 is thus of high translational significance because it provides a clear and robust preclinical demonstration that promoting the regeneration of glutamatergic synapses is a viable therapeutic approach in AD. It also suggests that ABPs and other regulators of the synaptic F-actin-based cytoskeleton offer viable targets to achieve this end.

Several aspects of the effects of SPG302 on spine density inform on its potential as a therapeutic at the clinical stage. First, it is notable that spine density was returned to levels not statistically different from WT controls. Moreover, the spines induced included both stubby and mushroom-shaped contacts that are preferentially lost in human AD brain and many AD mouse models [37, 64]. These observations suggest that SPG302 induces physiologically relevant spinogenesis, and that new synapses attain a normal distribution of shapes and, to the extent spine shape and synaptic strength are linked [65], efficacy states. This is remarkable given that there is no a priori reason to expect that the effects of any synaptogenic therapeutic agent will be constrained to those that are physiologically relevant, particularly against a background of AD-like pathology. We hypothesize that some instructive cue(s) may remain in the local dendritic microenvironment - perhaps in the extracellular matrix, the proximity of axons or their boutons, or local variations in glutamate concentration - that dictate where and how many new synapses should be formed, thus constraining SPG302's effects within physiologically relevant limits. A potentially informative observation in this regard comes from hibernation. It has been shown that synaptic density decreases during torpor coincident with an AD-like hyperphosphorylation and redistribution of Tau (presumably to prevent excitotoxicity in the context of the severe metabolic stresses of hibernation). Shortly after arousal and return to euthermia, both synaptic density and Tau phosphorylation and distribution normalize to normal levels [66-69]. Moreover, memory traces laid down before hibernation remain intact [70,71], suggesting that synapses are regenerated at physiologically relevant densities and efficacy states based on the persistence of some endogenous instructive cue. Second, the question arises as to whether SPG302-induced spinogenesis simply outpaces synaptic loss, which is already severe at $6 \mathrm{mo}$ in the $3 \times$ Tg-AD mouse, or if the effects of the drug create a new stable state that is disease modifying at some level of $A D$ pathogenesis. The present data do not answer this question, but it is reasonable to consider that normalization of synaptic density, particularly the density of large, high-efficacy mushroom-shaped spines, may revitalize trophic support and other mechanisms that aid in the maintenance of synapses and are disease modifying.

Another quality of SPG302's effects on spine density that informs on its potential utility as a therapeutic is its rapidity of action. In the present study, we observed rescue of synaptic and cognitive deficits within 1 month of dosing. Prototypes of SPG302 were effective at restoring motor performance in a rodent model of traumatic brain injury within 1 week of dosing [72], and in vitro they induce spinogenesis within an hour or less [73]. These data suggest that SPG302, and potentially other spinogenic small molecules, may be efficacious in humans on a much shorter time scale than has been expected of other candidate therapeutics that have been tested in AD. For example, treatment durations of 18 months or more were expected to be necessary to observe significant effects of $A \beta$-targeted monoclonal antibodies such as aducanumab [74], and this was only in terms of slowing disease progression, not reversing cognitive decline. While the molecular target of SPG302 is not here revealed, it is notable that its activity on the F-actin cytoskeleton is conceptually consistent with its rapid effects on spines and cognition. The formation and maturation of new spines, which depend on the formation of branched F-actin assemblies, can be triggered by very brief inductive events. For instance, in the developing hippocampus, induction of LTP with activity patterns that last on order of seconds can lead to spinogenesis that develops over the course of hours [75]. Based on the function of SPG302's target (for which SPG302 is highly selective), our working hypothesis is that SPG302 triggers the rapid formation of branched F-actin assemblies that are an essential basis of spine formation and maturation [45, 46]. Clinically, this may mean that even brief exposure to SPG302 on a daily basis may be sufficient to produce rapid therapeutic effects in $\mathrm{AD}$ and other synaptopathies. 
Though we did not have a specific prediction in this study as to the potential effects of SPG302 on levels of $A \beta$ and phospho-Tau, we nevertheless measured these hallmark features of AD molecular pathogenesis. SPG302 treatment did not alter the levels of $A \beta$ or phospho-Tau in the hippocampus of $3 \times \mathrm{Tg}-\mathrm{AD}$ mice relative to vehicle controls. The dissociation between phenotypic rescue and $A \beta$ load is not unprecedented. Rescue of synaptic density and cognition with no apparent effects on $A \beta$ load, or even an increase in $A \beta$, have been observed in preclinical studies that assessed the effects of modulating progranulin, microglial, and other factors in AD models $[76,77]$. Such findings accord with data from human studies showing that some subjects with robust $A \beta$ load can be cognitively normal. Spine density, particularly stubby and mushroom profiles, may be a key determinant of this dissociation insofar as subjects who are cognitively normal despite having high $A \beta$ load have more dendritic spines [37]. The lack of an effect of SPG302 on levels of phospho-Tau may pose a different question. The levels and regional extent of neurofibrillary tangles correlate with clinical status much better than $A \beta$ load. Moreover, there is compelling evidence that Tau pathology is a proximal cause of synaptic failure. This raises the question of how SPG302 can restore synaptic density and cognition in the context of high levels of phospho-Tau, particularly when the animal model used expresses the P301L mutation that is known to induce synapse loss in other tauopathy models as well [78]. While this will require more study, it is possible that cues for physiologically relevant densities and patterns of new synapse formation remain intact in the face of AD-like Tau pathology. This possibility finds support in observations that high levels of phospho-Tau occur in the brains of hibernating animals during torpor, when synaptic density is reduced, but are quickly diminished upon return to euthermia $[66,67]$. Insofar as synaptic density rebounds and memories remain, it is reasonable to assume that some cue for synaptogenesis - perhaps even a residual synaptic contact - survives robust Tau pathology. In $\mathrm{AD}$, 3-dimensional electron microscopy studies of synapses in the transentorhinal cortex suggest that at least some of the reduction in dendritic spines may be due to a conversion to shaft synapses [33].

Consistent with the formation of new axospinous synaptic contacts by SPG302, we observed increases in key synaptic proteins and a higher colocalization of pre- and post-synaptic markers. Importantly, synapse-like puncta immunopositive for the postsynaptic scaffolding protein, PSD95, were significantly increased by SPG302 treatment, as was the number of PSD95-positive elements colocalized with the presynaptic marker synaptophysin (at $30 \mathrm{mg} / \mathrm{kg}$ ). Prior work has shown that the synaptic content of PSD95 scales positively with spine size and synaptic efficacy [65, 79]. In addition, SPG302 significantly increased the levels of both PSD95 (at $30 \mathrm{mg}$ / $\mathrm{kg}$ ) and Drebrin A (at $3 \mathrm{mg} / \mathrm{kg}$ ) in synaptic fractions. Drebrin $\mathrm{A}$ is a postsynaptic ABP that promotes the enlargement and stabilization of synapses. Levels of Drebrin A, and spines containing the protein, decline early in $\mathrm{AD}$ and animal models [32, 48, 49]; its upregulation by SPG302 is consistent with the formation of larger, mushroom-shaped spines and suggests a normalization of synaptic cytoskeletal function by the drug. The above effects of SPG302, along with our Golgi staining and behavioral data (highly significant at both doses), indicate that SPG302 induced the formation of new synapses. Accordingly, we also observed increased levels of phospho-GluA1 in synaptic fractions. GluA1 is a subunit of amino-3-hydroxy5-methyl-4-isoxazolepropionic acid receptors (AMPARs), which mediate fast excitatory transmission and are impacted in $\mathrm{AD}[57,80]$. Our lab and others have shown that AMPA signaling is compromised early in the disease course in an AD transgenic mouse model [57, 81]. AMPARs are composed of four different subunits (GluA1-4, or Gria1-4). Of these, the role of the GluA1 subunit in learning and memory processes is the most widely investigated [82-84], including its phosphoregulation at several sites, including Ser831 and Ser845 [85]. Notably, a decline in AMPA signaling is associated with changes in the structure and number of dendritic spines in an AD model [57]. Rescue of phospho-GluA1 levels in synaptic fractions is yet another indication that SPG302 treatment increased the levels of axospinous glutamatergic contacts in the $3 \times T g-A D$ mouse model.

In sum, our data provide compelling preclinical evidence that SPG302 and related spinogenic small molecules may be of high therapeutic value in $\mathrm{AD}$, as well as other synaptopathies. At present, there are no FDA-approved therapies that address synapse loss in any of the synaptopathies, making SPG302 a highly differentiated candidate therapy for these disorders. Among the small set of therapeutics that may be able to regenerate lost synapses [38], SPG302 remains highly unique. The molecular target of SPG302 has not yet been the subject of clinical development in CNS conditions, and its mechanism of action may be superior to these other approaches. Moreover, it has excellent drug-like properties. A notable comparison is a class of HDAC inhibitors being developed for frontotemporal dementia and other neurodegenerative conditions [86]. These compounds increase the density of spine synapses in animal models, but only that of thin spines; thus, they do not restore the normal spectrum of synaptic shapes that includes mushroom and stubby spines. In principle, SPG302 could be used as a monotherapy or as an add-on to other therapeutics in development that target upstream aspects of $\mathrm{AD}$ pathogenesis at the molecular level. Regarding the latter, it is important to consider that $\mathrm{AD}$ involves more than degeneration - it is also a failure of regenerative processes that can compensate for synaptic failure. 


\section{Conclusions}

New disease-modifying therapeutics that target degenerative mechanisms may halt AD progression, but fail to elicit gains in cognition that actually improve the quality of life and reduce the economic and emotional burden AD imposes on affected individuals and their families. Should SPG302 prove safe and well tolerated in humans, the rapid regenerative effects of SPG302 that we report here raise the prospect of a much different clinical experience than has been the case so far for $\mathrm{AD}$ and other synaptopathies in terms of duration of treatment, outcome measures, and expected effect sizes.

\begin{abstract}
Abbreviations 3xTg-AD : Triple transgenic Alzheimer's disease; $\mathrm{A} \beta$ : Amyloid-beta; ABPs : Actin-binding proteins; AChE : Acetyl cholinesterase; AD : Alzheimer's disease; AMPAR : Amino-3-hydroxy5-methyl-4-isoxazolepropionic acid receptor; ANOVA : Analysis of variance; BSA : Bovine serum albumin; CFC : Contextual fear conditioning; F-actin : Filamentous actin; KI : Knock in; LTD : Long-term depression; LTP : Long-term potentiation; MWM : Morris water maze; NMDAR : N-methyl-D-aspartate receptor; PBS : Phosphate buffered saline; PSD95 : Postsynaptic density protein 95 ; $\mathrm{sr}$ : Stratum radiatum; SV2A : Synaptic vesicle glycoprotein 2; TBS : Tris-buffered saline; WB : Western blot; WT : Wild type
\end{abstract}

Supplementary Information The online version contains supplementary material available at https://doi.org/10.1007/s13311-021-01143-1.

Required Author Forms Disclosure forms provided bythe authors are available with the online version of this article.

Funding This study was supported by the National Institute of Health (NIH) NIH/NIA 1R43 AG058278-01A1 (V.S.F. and F.M.L).

\section{Declarations}

Ethical Approval and Consent to Participate Approval from the Institutional Animal Care and Use Committee of University of California Irvine was obtained prior to all animal-related studies (IACUC protocol \#AUP-17-09).

Consent for Publication All authors have approved the contents of this manuscript and provided consent for publication.

Competing Interests P.W.V., S.T.S. and V.F.S declare that they are members of the executive team of Spinogenix where they are developing SPG compounds as therapeutics for synaptopathies. All other authors declare no competing interests.

Open Access This article is licensed under a Creative Commons Attribution 4.0 International License, which permits use, sharing, adaptation, distribution and reproduction in any medium or format, as long as you give appropriate credit to the original author(s) and the source, provide a link to the Creative Commons licence, and indicate if changes were made. The images or other third party material in this article are included in the article's Creative Commons licence, unless indicated otherwise in a credit line to the material. If material is not included in the article's Creative Commons licence and your intended use is not permitted by statutory regulation or exceeds the permitted use, you will need to obtain permission directly from the copyright holder. To view a copy of this licence, visit http://creativecommons.org/licenses/by/4.0/.

\section{References}

1. 2020 Alzheimer's disease facts and figures. Alzheimer's Dement [Internet]. John Wiley and Sons Inc.; 2020 [cited 2020 Dec 9];16:391-460. Available from: https://onlinelibrary.wiley.com/ doi/abs/10.1002/alz.12068

2. Elmaleh DR, Farlow MR, Conti PS, Tompkins RG, Kundakovic L, Tanzi RE. Developing Effective Alzheimer's Disease Therapies: Clinical Experience and Future Directions [Internet]. J. Alzheimer's Dis. IOS Press; 2019 [cited 2020 Dec 9]. p. 715-32. Available from: https://pubmed.ncbi.nlm.nih.gov/31476157/

3. Cummings J, Lee G, Ritter A, Sabbagh M, Zhong K. Alzheimer's disease drug development pipeline: 2020. Alzheimer's Dement Transl Res Clin Interv. Wiley; 2020;6.

4. Selkoe DJ. Alzheimer's disease is a synaptic failure. Science (80-. ). 2002. p. 789-91.

5. DeKosky ST, Scheff SW. Synapse loss in frontal cortex biopsies in Alzheimer's disease: Correlation with cognitive severity. Ann Neurol [Internet]. Ann Neurol; 1990 [cited 2020 Dec 9];27:45764. Available from: https://pubmed.ncbi.nlm.nih.gov/2360787/

6. Terry RD, Masliah E, Salmon DP, Butters N, DeTeresa R, Hill R, et al. Physical basis of cognitive alterations in alzheimer's disease: Synapse loss is the major correlate of cognitive impairment. Ann Neurol [Internet]. Ann Neurol; 1991 [cited 2020 Dec 9];30:57280. Available from: https://pubmed.ncbi.nlm.nih.gov/1789684/

7. Henstridge CM, Pickett E, Spires-Jones TL. Synaptic pathology: A shared mechanism in neurological disease [Internet]. Ageing Res. Rev. Elsevier Ireland Ltd; 2016 [cited 2020 Dec 9]. p. 72-84. Available from: https://pubmed.ncbi.nlm.nih.gov/27108053/

8. Herms J, Dorostkar MM. Dendritic Spine Pathology in Neurodegenerative Diseases [Internet]. Annu. Rev. Pathol. Mech. Dis. Annual Reviews Inc.; 2016 [cited 2020 Dec 9]. p. 221-50. Available from: https://pubmed.ncbi.nlm.nih.gov/26907528/

9. Hyman BT, Van Hoesen GW, Damasio AR, Barnes CL. Alzheimer's disease: Cell-specific pathology isolates the hippocampal formation. Science (80- ) [Internet]. Science; 1984 [cited 2020 Dec 9];225:116870. Available from: https://pubmed.ncbi.nlm.nih.gov/6474172/

10. Allen G, Barnard H, McColl R, Hester AL, Fields JA, Weiner MF, et al. Reduced hippocampal functional connectivity in Alzheimer disease. Arch Neurol [Internet]. Arch Neurol; 2007 [cited 2020 Dec 9];64:14827. Available from: https://pubmed.ncbi.nlm.nih.gov/17923631/

11. Reid AT, Evans AC. Structural networks in Alzheimer's disease. Eur Neuropsychopharmacol [Internet]. Eur Neuropsychopharmacol; 2013 [cited 2020 Dec 9];23:63-77. Available from: https:// pubmed.ncbi.nlm.nih.gov/23294972/

12. Davies CA, Mann DMA, Sumpter PQ, Yates PO. A quantitative morphometric analysis of the neuronal and synaptic content of the frontal and temporal cortex in patients with Alzheimer's disease. J Neurol Sci [Internet]. J Neurol Sci; 1987 [cited 2020 Dec 9]; 78:15164. Available from: https://pubmed.ncbi.nlm.nih.gov/3572454/

13. Masliah E, Terry RD, DeTeresa RM, Hansen LA. Immunohistochemical quantification of the synapse-related protein synaptophysin in Alzheimer disease. Neurosci Lett [Internet]. Neurosci Lett; 1989 [cited 2020 Dec 9];103:234-9. Available from: https:// pubmed.ncbi.nlm.nih.gov/2505201/

14. Masliah E, Mallory M, Alford M, DeTeresa R, Hansen LA, McKeel $\mathrm{DW}$, et al. Altered expression of synaptic proteins occurs early during progression of Alzheimer's disease. Neurology [Internet]. 2001 [cited 2020 Mar 2];56:127-9. Available from: http://www.ncbi.nlm. nih.gov/pubmed/11148253 
15. Scheff SW, Price DA. Alzheimer's disease-related alterations in synaptic density: Neocortex and hippocampus [Internet]. J. Alzheimer's Dis. IOS Press; 2006 [cited 2020 Dec 9]. p. 101-15. Available from: https://pubmed.ncbi.nlm.nih.gov/16914849/

16. Scheff SW, Price DA, Schmitt FA, Dekosky ST, Mufson EJ. Synaptic alterations in CA1 in mild Alzheimer disease and mild cognitive impairment. Neurology [Internet]. Neurology; 2007 [cited 2020 Dec 9];68:1501-8. Available from: https://pubmed.ncbi.nlm.nih. gov/17470753/

17. Merino-Serrais P, Benavides-Piccione R, Blazquez-Llorca L, Kastanauskaite A, Rábano A, Avila J, et al. The influence of phospho-tau on dendritic spines of cortical pyramidal neurons in patients with Alzheimer's disease. Brain [Internet]. Oxford University Press; 2013 [cited 2020 Dec 9];136:1913-28. Available from: https://pubmed.ncbi.nlm.nih.gov/23715095/

18. Scheff SW, Price DA, Ansari MA, Roberts KN, Schmitt FA, Ikonomovic MD, et al. Synaptic change in the posterior cingulate gyrus in the progression of Alzheimer's disease. J Alzheimer's Dis [Internet]. IOS Press; 2015 [cited 2020 Dec 9];43:1073-90. Available from: https://pubmed.ncbi.nlm.nih.gov/25147118/

19. Scheff SW, Price DA. Synaptic pathology in Alzheimer's disease: A review of ultrastructural studies. Neurobiol Aging [Internet]. Elsevier Inc.; 2003 [cited 2020 Dec 9]. p. 1029-46. Available from: https://pubmed.ncbi.nlm.nih.gov/14643375/

20. Dorostkar MM, Zou C, Blazquez-Llorca L, Herms J. Analyzing dendritic spine pathology in Alzheimer's disease: problems and opportunities [Internet]. Acta Neuropathol. Springer Verlag; 2015 [cited 2020 Dec 9]. Available from: https://pubmed.ncbi.nlm.nih. gov/26063233/

21. Nimchinsky EA, Sabatini BL, Svoboda K. Structure and function of dendritic spines [Internet]. Annu. Rev. Physiol. Annu Rev Physiol; 2002 [cited 2020 Dec 9]. p. 313-53. Available from: https://pubmed.ncbi.nlm.nih.gov/11826272/

22. Bailey CH, Kandel ER, Harris KM. Structural components of synaptic plasticity and memory consolidation. Cold Spring Harb Perspect Biol [Internet]. Cold Spring Harbor Laboratory Press; 2015 [cited 2020 Dec 9];7:1-29. Available from: https://pubmed. ncbi.nlm.nih.gov/26134321/

23. Fowler SW, Chiang ACA, Savjani RR, Larson ME, Sherman MA, Schuler DR, et al. Genetic modulation of soluble A $\beta$ rescues cognitive and synaptic impairment in a mouse model of Alzheimer's disease. J Neurosci [Internet]. Society for Neuroscience; 2014 [cited 2020 Dec 9];34:7871-85. Available from: https://pubmed. ncbi.nlm.nih.gov/24899710/

24. Neuman KM, Molina-Campos E, Musial TF, Price AL, Oh KJ, Wolke ML, et al. Evidence for Alzheimer's disease-linked synapse loss and compensation in mouse and human hippocampal CA1 pyramidal neurons. Brain Struct Funct [Internet]. Springer Verlag; 2015 [cited 2020 Dec 9];220:3143-65. Available from: https:// pubmed.ncbi.nlm.nih.gov/25031178/

25. Price KA, Varghese M, Sowa A, Yuk F, Brautigam H, Ehrlich ME, et al. Altered synaptic structure in the hippocampus in a mouse model of Alzheimer's disease with soluble amyloid- $\beta$ oligomers and no plaque pathology. Mol Neurodegener [Internet]. Mol Neurodegener; 2014 [cited $2020 \mathrm{Dec}$ 9];9:41. Available from: https:// pubmed.ncbi.nlm.nih.gov/25312309/

26. Alonso-Nanclares L, Merino-Serrais P, Gonzalez S, Defelipe J. Synaptic changes in the dentate gyrus of APP/PS1 transgenic mice revealed by electron microscopy. J Neuropathol Exp Neurol [Internet]. J Neuropathol Exp Neurol; 2013 [cited 2020 Dec 9];72:38695. Available from: https://pubmed.ncbi.nlm.nih.gov/23584198/

27. Pozueta J, Lefort R, Shelanski ML. Synaptic changes in Alzheimer's disease and its models [Internet]. Neuroscience. Neuroscience; 2013 [cited 2020 Dec 9]. p. 51-65. Available from: https:// pubmed.ncbi.nlm.nih.gov/22687952/
28. Shankar GM, Li S, Mehta TH, Garcia-Munoz A, Shepardson NE, Smith I, et al. Amyloid- $\beta$ protein dimers isolated directly from Alzheimer's brains impair synaptic plasticity and memory. Nat Med [Internet]. Nat Med; 2008 [cited 2020 Dec 9];14:837-42. Available from: https://pubmed.ncbi.nlm.nih.gov/18568035/

29. Akram A, Christoffel D, Rocher AB, Bouras C, Kövari E, Perl DP, et al. Stereologic estimates of total spinophilin-immunoreactive spine number in area 9 and the CA1 field: Relationship with the progression of Alzheimer's disease. Neurobiol Aging [Internet]. Neurobiol Aging; 2008 [cited 2020 Dec 9];29:1296-307. Available from: https://pubmed.ncbi.nlm.nih.gov/17420070/

30. Mi Z, Abrahamson EE, Ryu AY, Fish KN, Sweet RA, Mufson $\mathrm{EJ}$, et al. Loss of precuneus dendritic spines immunopositive for spinophilin is related to cognitive impairment in early Alzheimer's disease. Neurobiol Aging [Internet]. Elsevier Inc.; 2017 [cited 2020 Dec 9];55:159-66. Available from: https://pubmed.ncbi.nlm. nih.gov/28259365/

31. Kim T, Vidal GS, Djurisic M, William CM, Birnbaum ME, Garcia $\mathrm{KC}$, et al. Human LilrB2 is a $\beta$-amyloid receptor and its murine homolog PirB regulates synaptic plasticity in an Alzheimer's model. Science (80- ) [Internet]. American Association for the Advancement of Science; 2013 [cited 2020 Dec 9];341:1399-404. Available from: https://pubmed.ncbi.nlm.nih.gov/24052308/

32. Shirao T, Hanamura K, Koganezawa N, Ishizuka Y, Yamazaki H, Sekino Y. The role of drebrin in neurons [Internet]. J. Neurochem. Blackwell Publishing Ltd; 2017 [cited 2020 Dec 9]. p. 819-34. Available from: https://pubmed.ncbi.nlm.nih.gov/28199019/

33. Domínguez-Álvaro M, Montero-Crespo M, Blazquez-Llorca L, DeFelipe J, Alonso-Nanclares L. 3D electron microscopy study of synaptic organization of the normal human transentorhinal cortex and its possible alterations in alzheimer's disease. eNeuro [Internet]. Society for Neuroscience; 2019 [cited 2020 Dec 9];6:1-17. Available from: https://pubmed.ncbi.nlm.nih.gov/31217195/

34. Domínguez-álvaro M, Montero-Crespo M, Blazquez-Llorca L, Insausti R, DeFelipe J, Alonso-Nanclares L. Three-dimensional analysis of synapses in the transentorhinal cortex of Alzheimer's disease patients. Acta Neuropathol Commun [Internet]. BioMed Central Ltd.; 2018 [cited 2020 Dec 9];6. Available from: https:// pubmed.ncbi.nlm.nih.gov/29499755/

35. Chen MK, Mecca AP, Naganawa M, Finnema SJ, Toyonaga T, Lin SF, et al. Assessing Synaptic Density in Alzheimer Disease with Synaptic Vesicle Glycoprotein 2A Positron Emission Tomographic Imaging. JAMA Neurol [Internet]. American Medical Association; 2018 [cited 2020 Dec 9];75:1215-24. Available from: https://pubmed.ncbi.nlm.nih.gov/30014145/

36. Mecca AP, Chen MK, O'Dell RS, Naganawa M, Toyonaga T, Godek TA, et al. In vivo measurement of widespread synaptic loss in Alzheimer's disease with SV2A PET. Alzheimer's Dement [Internet]. John Wiley and Sons Inc.; 2020 [cited 2020 Dec 9];16:974-82. Available from: https://pubmed.ncbi.nlm.nih.gov/ 32400950/

37. Boros BD, Greathouse KM, Gentry EG, Curtis KA, Birchall EL, Gearing M, et al. Dendritic spines provide cognitive resilience against Alzheimer's disease. Ann Neurol [Internet]. John Wiley and Sons Inc.; 2017 [cited 2020 Dec 9];82:602-14. Available from: https://pubmed.ncbi.nlm.nih.gov/28921611/

38. Jackson J, Jambrina E, Li J, Marston H, Menzies F, Phillips K, et al. Targeting the Synapse in Alzheimer's Disease. Front Neurosci. Frontiers Media SA; 2019;13.

39. Fifkovà E, Delay RJ. Cytoplasmic actin in neuronal processes as a possible mediator of synaptic plasticity. J Cell Biol [Internet]. J Cell Biol; 1982 [cited 2020 Dec 14];95:345-50. Available from: https://pubmed.ncbi.nlm.nih.gov/6890558/ 
40. Matus A, Ackermann M, Pehling G, Byers HR, Fujiwara K. High actin concentrations in brain dendritic spines and postsynaptic densities. Proc Natl Acad Sci U S A [Internet]. Proc Natl Acad Sci U S A; 1982 [cited 2020 Dec 14];79:7590-4. Available from: https://pubmed.ncbi.nlm.nih.gov/6760199/

41. Bellot A, Guivernau B, Tajes M, Bosch-Morató M, VallsComamala V, Muñoz FJ. The structure and function of actin cytoskeleton in mature glutamatergic dendritic spines. Brain Res [Internet]. 2014 [cited 2019 Aug 29];1573:1-16. Available from: http://www.ncbi.nlm.nih.gov/pubmed/24854120

42. Fischer M, Kaech S, Knutti D, Matus A. Rapid actin-based plasticity in dendritic spines. Neuron [Internet]. Cell Press; 1998 [cited 2020 Dec 14];20:847-54. Available from: https://pubmed.ncbi. nlm.nih.gov/9620690/

43. Matus A. Actin-based plasticity in dendritic spines [Internet]. Science (80-. ). Science; 2000 [cited 2020 Dec 14]. p. 754-8. Available from: https://pubmed.ncbi.nlm.nih.gov/11052932/

44. Borovac J, Bosch M, Okamoto K. Regulation of actin dynamics during structural plasticity of dendritic spines: Signaling messengers and actin-binding proteins. Mol Cell Neurosci [Internet]. 2018 [cited 2019 Aug 29];91:122-30. Available from: http://www.ncbi.nlm.nih.gov/pubmed/30004015

45. Korobova F, Svitkina T. Molecular architecture of synaptic actin cytoskeleton in hippocampal neurons reveals a mechanism of dendritic spine morphogenesis. Mol Biol Cell [Internet]. 2010 [cited 2019 Aug 29];21:165-76. Available from: http://www. ncbi.nlm.nih.gov/pubmed/19889835

46. Saarikangas J, Kourdougli N, Senju Y, Chazal G, Segerstråle M, Minkeviciene R, et al. MIM-Induced Membrane Bending Promotes Dendritic Spine Initiation. Dev Cell [Internet]. Cell Press; 2015 [cited 2020 Dec 14];33:644-59. Available from: https://pubmed.ncbi.nlm.nih.gov/26051541/

47. Koganezawa N, Hanamura K, Sekino Y, Shirao T. The role of drebrin in dendritic spines [Internet]. Mol. Cell. Neurosci. Academic Press Inc.; 2017 [cited 2020 Feb 27]. p. 85-92. Available from: http://www.ncbi.nlm.nih.gov/pubmed/28161364

48. Counts SE, Nadeem M, Lad SP, Wuu J, Mufson EJ. Differential expression of synaptic proteins in the frontal and temporal cortex of elderly subjects with mild cognitive impairment. J Neuropathol Exp Neurol [Internet]. 2006 [cited 2020 Feb 26];65:592-601. Available from: http://www.ncbi.nlm.nih.gov/ pubmed/16783169

49. Counts SE, He B, Nadeem M, Wuu J, Scheff SW, Mufson EJ. Hippocampal drebrin loss in mild cognitive impairment. Neurodegener Dis [Internet]. 2012 [cited 2020 Mar 31];10:216-9. Available from: http://www.ncbi.nlm.nih.gov/pubmed/22310934

50. Shankar GM, Bloodgood BL, Townsend M, Walsh DM, Selkoe DJ, Sabatini BL. Natural oligomers of the Alzheimer amyloid- $\beta$ protein induce reversible synapse loss by modulating an NMDAtype glutamate receptor-dependent signaling pathway. J Neurosci [Internet]. J Neurosci; 2007 [cited 2020 Dec 14];27:2866-75. Available from: https://pubmed.ncbi.nlm.nih.gov/17360908/

51. Zhou Q, Homma KJ, Poo MM. Shrinkage of dendritic spines associated with long-term depression of hippocampal synapses. Neuron [Internet]. Neuron; 2004 [cited 2020 Dec 14];44:749-57. Available from: https://pubmed.ncbi.nlm.nih.gov/15572107/

52. Pontrello CG, Sun MY, Lin A, Fiacco TA, DeFea KA, Ethell IM. Cofilin under control of $\beta$-arrestin-2 in NMDA-dependent dendritic spine plasticity, long-term depression (LTD), and learning. Proc Natl Acad Sci U S A [Internet]. Proc Natl Acad Sci U S A; 2012 [cited 2020 Dec 14];109. Available from: https://pubmed. ncbi.nlm.nih.gov/22308427/

53. Rust MB. ADF/cofilin: A crucial regulator of synapse physiology and behavior [Internet]. Cell. Mol. Life Sci. Birkhauser Verlag AG; 2015 [cited 2020 Dec 14]. p. 3521-9. Available from: https:// pubmed.ncbi.nlm.nih.gov/26037722/
54. Klára FE, Magdolna P, Petra S, Zoltán J, János K. Az alzheimerkór citoszkeletális változásai: A terápiás remény "váza"? [Internet]. Neuropsychopharmacol. Hungarica. Neuropsychopharmacol Hung; 2011 [cited 2020 Dec 14]. p. 163-71. Available from: https://pubmed.ncbi.nlm.nih.gov/21876225/

55. Minamide LS, Striegl AM, Boyle JA, Meberg PJ, Bamburg JR. Neurodegenerative stimuli induce persistent ADF/cofilin-actin rods that disrupt distal neurite function. Nat Cell Biol [Internet]. Nat Cell Biol; 2000 [cited 2020 Dec 14];2:628-36. Available from: https://pubmed.ncbi.nlm.nih.gov/10980704/

56. Oddo S, Caccamo A, Shepherd JD, Murphy MP, Golde TE, Kayed $\mathrm{R}$, et al. Triple-transgenic model of Alzheimer's disease with plaques and tangles: intracellular Abeta and synaptic dysfunction. Neuron [Internet]. 2003 [cited 2019 Apr 16];39:409-21. Available from: http://www.ncbi.nlm.nih.gov/pubmed/12895417

57. Baglietto-Vargas D, Prieto GA, Limon A, Forner S, RodriguezOrtiz CJ, Ikemura K, et al. Impaired AMPA signaling and cytoskeletal alterations induce early synaptic dysfunction in a mouse model of Alzheimer's disease. Aging Cell. Blackwell Publishing Ltd; 2018;17.

58. Baglietto-Vargas D, Medeiros R, Martinez-Coria H, Laferla FM, Green KN. Mifepristone alters amyloid precursor protein processing to preclude amyloid beta and also reduces tau pathology. Biol Psychiatry. 2013;74:357-66.

59. Trujillo-Estrada L, Nguyen C, da Cunha C, Cai L, Forner S, Martini $\mathrm{AC}$, et al. Tau underlies synaptic and cognitive deficits for type 1, but not type 2 diabetes mouse models. Aging Cell [Internet]. 2019 [cited 2019 Apr 3];e12919. Available from: http://doi.wiley.com/10.1111/ acel.12919

60. Baglietto-Vargas D, Chen Y, Suh D, Ager RR, Rodriguez-Ortiz CJ, Medeiros R, et al. Short-term modern life-like stress exacerbates A $\beta$-pathology and synapse loss in $3 x T g-A D$ mice. J Neurochem [Internet]. 2015 [cited 2017 Jul 11];134:915-26. Available from: http://doi.wiley.com/10.1111/jnc.13195

61. Savioz A, Leuba G, Vallet PG. A framework to understand the variations of PSD-95 expression in brain aging and in Alzheimer's disease. Ageing Res Rev [Internet]. 2014 [cited 2019 Aug 29];18:86-94. Available from: http://www.ncbi.nlm.nih.gov/pubmed/25264360

62. Mendoza-Torreblanca JG, Vanoye-Carlo A, Phillips-Farfán BV, Carmona-Aparicio L, Gómez-Lira G. Synaptic vesicle protein 2A: Basic facts and role in synaptic function. Eur. J. Neurosci. Blackwell Publishing Ltd; 2013. p. 3529-39.

63. Querfurth HW, LaFerla FM. Alzheimer's disease. N Engl J Med [Internet]. 2010 [cited 2018 Oct 23];362:329-44. Available from: http://www.nejm.org/doi/abs/10.1056/NEJMra0909142

64. Zhang H, Sun S, Wu L, Pchitskaya E, Zakharova O, Tacer KF, et al. Store-operated calcium channel complex in postsynaptic spines: A new therapeutic target for alzheimer's disease treatment. J Neurosci [Internet]. Society for Neuroscience; 2016 [cited 2020 Dec 14];36:11837-50. Available from: https://pubmed.ncbi.nlm.nih.gov/ 27881772/

65. Matsuzaki M, Ellis-Davies GCR, Nemoto T, Miyashita Y, Iino M, Kasai H. Dendritic spine geometry is critical for AMPA receptor expression in hippocampal CA1 pyramidal neurons. Nat Neurosci [Internet]. Nat Neurosci; 2001 [cited 2020 Dec 14];4:1086-92. Available from: https://pubmed.ncbi.nlm.nih.gov/11687814/

66. Arendt T, Stieler J, Strijkstra AM, Hut RA, Rüdiger J, Van der Zee EA, et al. Reversible paired helical filament-like phosphorylation of tau is an adaptive process associated with neuronal plasticity in hibernating animals. J Neurosci [Internet]. Society for Neuroscience; 2003 [cited 2020 Dec 14];23:6972-81. Available from: https://pubmed.ncbi.nlm.nih.gov/12904458/

67. Stieler JT, Bullmann T, Kohl F, Tøien O, Brückner MK, Härtig $\mathrm{W}$, et al. The physiological link between metabolic rate depression and tau phosphorylation in mammalian hibernation. PLoS 
One [Internet]. PLoS One; 2011 [cited 2020 Dec 14];6. Available from: https://pubmed.ncbi.nlm.nih.gov/21267079/

68. Popov VI, Medvedev NI, Patrushev I V., Ignat'ev DA, Morenkov ED, Stewart MG. Reversible reduction in dendritic spines in CA1 of rat and ground squirrel subjected to hypothermia-normothermia in vivo: A three-dimensional electron microscope study. Neuroscience [Internet]. Elsevier Ltd; 2007 [cited 2020 Dec 14];149:54960. Available from: https://pubmed.ncbi.nlm.nih.gov/17919827/

69. Popov VI, Bocharova LS, Bragin AG. Repeated changes of dendritic morphology in the hippocampus of ground squirrels in the course of hibernation. Neuroscience [Internet]. Neuroscience; 1992 [cited 2020 Dec 14];48:45-51. Available from: https://pubmed. ncbi.nlm.nih.gov/1584424/

70. Bullmann T, Seeger G, Stieler J, Hanics J, Reimann K, Kretzschmann TP, et al. Tau phosphorylation-associated spine regression does not impair hippocampal-dependent memory in hibernating golden hamsters. Hippocampus [Internet]. John Wiley and Sons Inc.; 2016 [cited 2020 Dec 14];26:301-18. Available from: https://pubmed.ncbi.nlm.nih.gov/26332578/

71. Arendt T, Bullmann T. Neuronal plasticity in hibernation and the proposed role of the microtubule-associated protein tau as a "master switch" regulating synaptic gain in neuronal networks [Internet]. Am. J. Physiol. - Regul. Integr. Comp. Physiol. Am J Physiol Regul Integr Comp Physiol; 2013 [cited 2020 Dec 14]. Available from: https://pubmed.ncbi.nlm.nih.gov/23824962/

72. Zhang Y, Chopp M, Rex CS, Simmon VF, Sarraf ST, Zhang ZG, et al. A Small Molecule Spinogenic Compound Enhances Functional Outcome and Dendritic Spine Plasticity in a Rat Model of Traumatic Brain Injury. J Neurotrauma. Mary Ann Liebert Inc.; 2019;36:589-600.

73. Cifelli JL, Chung TS, Liu H, Prangkio P, Mayer M, Yang J. Benzothiazole Amphiphiles Ameliorate Amyloid $\beta$-Related Cell Toxicity and Oxidative Stress. ACS Chem Neurosci [Internet]. American Chemical Society; 2016 [cited 2020 Dec 14];7:682-8. Available from: https://pubmed.ncbi.nlm.nih.gov/27055069/

74. Selkoe DJ. Alzheimer disease and aducanumab: adjusting our approach [Internet]. Nat. Rev. Neurol. Nature Publishing Group; 2019 [cited 2020 Dec 14]. p. 365-6. Available from: https://pubmed. ncbi.nlm.nih.gov/31138932/

75. Harris KM. Structural LTP: from synaptogenesis to regulated synapse enlargement and clustering [Internet]. Curr. Opin. Neurobiol. Elsevier Ltd; 2020 [cited 2020 Dec 14]. p. 189-97. Available from: https:// pubmed.ncbi.nlm.nih.gov/32659458/

76. Takahashi H, Klein ZA, Bhagat SM, Kaufman AC, Kostylev MA, Ikezu T, et al. Opposing effects of progranulin deficiency on amyloid and tau pathologies via microglial TYROBP network. Acta Neuropathol [Internet]. Springer Verlag; 2017 [cited 2020 Dec 14];133:785-807. Available from: https://pubmed.ncbi.nlm.nih. gov/28070672/
77. Dagher NN, Najafi AR, Kayala KMN, Elmore MRP, White TE, Medeiros R, et al. Colony-stimulating factor 1 receptor inhibition prevents microglial plaque association and improves cognition in 3xTg-AD mice. J Neuroinflammation [Internet]. 2015 [cited 2018 Jan 17];12:139. Available from: http://www.jneuroinflammation. com/content/12/1/139

78. Kopeikina KJ, Polydoro M, Tai HC, Yaeger E, Carlson GA, Pitstick R, et al. Synaptic alterations in the rTg4510 mouse model of tauopathy. J Comp Neurol [Internet]. J Comp Neurol; 2013 [cited 2020 Dec 16];521:1334-53. Available from: https:// pubmed.ncbi.nlm.nih.gov/23047530/

79. Cane M, Maco B, Knott G, Holtmaat A. The relationship between PSD-95 clustering and spine stability In Vivo. J Neurosci [Internet]. J Neurosci; 2014 [cited 2020 Dec 14];34:2075-86. Available from: https://pubmed.ncbi.nlm.nih.gov/24501349/

80. Jurado S, Maria Gonzalez-Gonzalez I, Shepherd JD, Anggono V. AMPA Receptor Trafficking in Natural and Pathological Aging. 2018 [cited 2020 Mar 4]; Available from: http://www.alz.org/facts/

81. Reinders NR, Pao Y, Renner MC, Da Silva-Matos CM, Lodder TR, Malinow R, et al. Amyloid- $\beta$ effects on synapses and memory require AMPA receptor subunit GluA3. 2016;

82. Hanley JG. AMPA receptor trafficking pathways and links to dendritic spine morphogenesis. Cell Adh. Migr. 2008. p. 276-82.

83. Guntupalli S, Widagdo J, Anggono V. Amyloid- $\beta$-Induced Dysregulation of AMPA Receptor Trafficking. Neural Plast [Internet]. 2016 [cited 2020 Mar 2];2016:3204519. Available from: http://www.ncbi. nlm.nih.gov/pubmed/27073700

84. Vanderklish P, Neve R, Bahr BA, Arai A, Hennegriff M, Larson $\mathrm{J}$, et al. Translational suppression of a glutamate receptor subunit impairs long-term potentiation. Synapse [Internet]. Synapse; 1992 [cited 2020 Dec 14];12:333-7. Available from: https://pubmed. ncbi.nlm.nih.gov/1465743/

85. Olivito L, Saccone P, Perri V, Bachman JL, Fragapane P, Mele A, et al. Phosphorylation of the AMPA receptor GluA1 subunit regulates memory load capacity. Brain Struct Funct. Springer Verlag; 2016;221:591-603.

86. Fuller NO, Pirone A, Lynch BA, Hewitt MC, Quinton MS, McKee TD, et al. CoREST Complex-Selective Histone Deacetylase Inhibitors Show Prosynaptic Effects and an Improved Safety Profile to Enable Treatment of Synaptopathies. ACS Chem Neurosci [Internet]. American Chemical Society; 2019 [cited 2020 Dec 14];10:1729-43. Available from: https://pubmed.ncbi.nlm.nih.gov/30496686/

Publisher's Note Springer Nature remains neutral with regard to jurisdictional claims in published maps and institutional affiliations. 